DIW BERLIN

Discussion

Papers

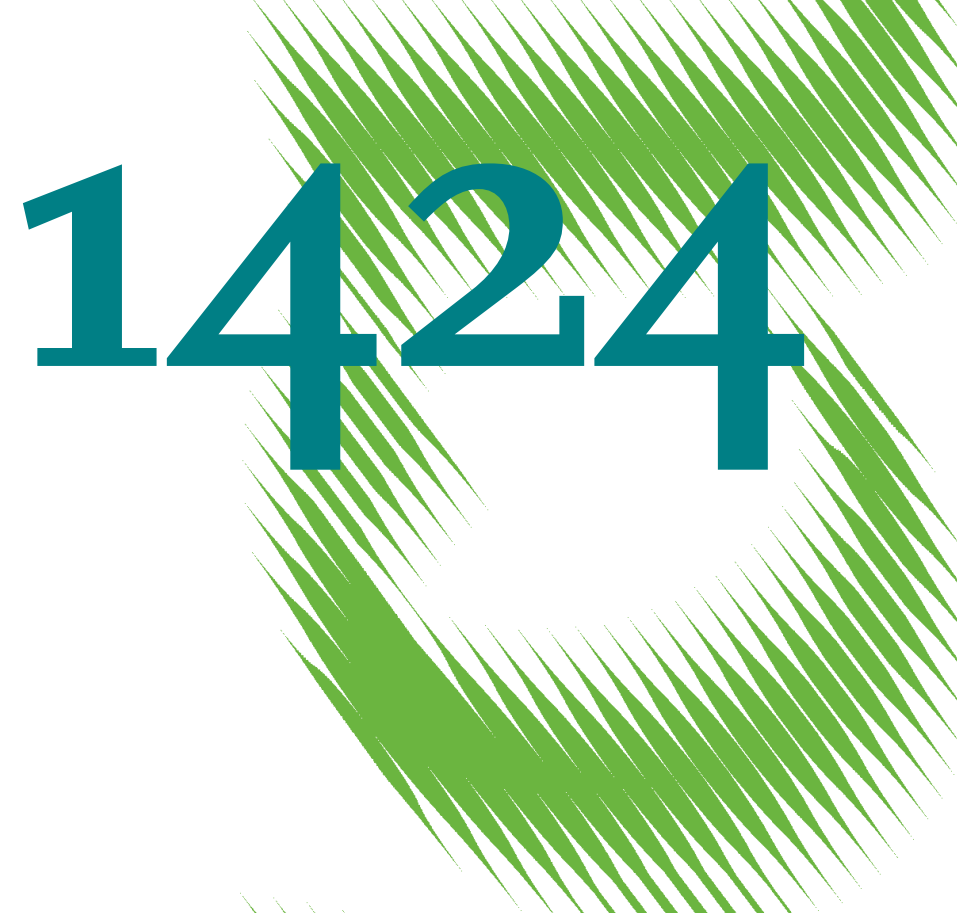

The Tax-Rate Elasticity of Local Business Profits 
Opinions expressed in this paper are those of the author(s) and do not necessarily reflect views of the institute.

IMPRESSUM

(C) DIW Berlin, 2014

DIW Berlin

German Institute for Economic Research

Mohrenstr. 58

10117 Berlin

Tel. +49 (30) $89789-0$

Fax +49 (30) $89789-200$

http://www.diw.de

ISSN electronic edition 1619-4535

Papers can be downloaded free of charge from the DIW Berlin website:

http://www.diw.de/discussionpapers

Discussion Papers of DIW Berlin are indexed in RePEc and SSRN:

http://ideas.repec.org/s/diw/diwwpp.html

http://www.ssrn.com/link/DIW-Berlin-German-Inst-Econ-Res.html 


\title{
The Tax-rate Elasticity of Local Business Profits*
}

\author{
Frank M. Fossen ${ }^{\dagger} \quad$ Viktor Steiner ${ }^{\ddagger}$
}

November 5, 2014

\begin{abstract}
:
Local business profits respond to local business tax (LBT) rates that vary across municipalities. We estimate that a one percent increase in the LBT rate decreases the LBT base by 0.45 percent, based on the universe of German LBT return files, which include corporations and unincorporated businesses. However, the fiscal equalization scheme largely compensates municipalities for the loss in the LBT base when they increase the LBT rate. Our estimates suggest that using tax revenue data instead of tax return data, as commonly done in the literature, results in a significant bias of the elasticity away from zero.
\end{abstract}

JEL classification: H25, H71.

Keywords: local business tax, corporate tax, tax responsiveness, tax-rate elasticity

\footnotetext{
* Acknowledgement: We would like to thank Ronny Freier, Frank Hechtner, Jochen Hundsdoerfer, Martin Simmler, Florian Walch, and participants at a seminar at Freie Universität Berlin in July 2010 for helpful and valuable comments. We are grateful to the helpful staff at the Research Data Centers of the Statistical Offices of Berlin-Brandenburg and Hesse for providing access to the confidential tax return data by means of controlled remote computing. Frank Fossen conducted part of this project as a visiting researcher at the University of California, Santa Cruz. He thanks the Fritz Thyssen Foundation for financial support of this research visit.

${ }^{\dagger}$ Freie Universität Berlin, DIW Berlin and IZA. Corresponding author, address: Freie Universität Berlin, Boltzmannstr. 20, 14195 Berlin, Germany, phone: +49 30838 52510, e-mail: frank.fossen@fu-berlin.de.

‡Freie Universität Berlin, Boltzmannstr. 20, 14195 Berlin, Germany, phone: +49 30838 54371, e-mail: viktor.steiner@fu-berlin.de.
} 


\section{Introduction}

When governments change corporate and other business tax rates, the profits of firms may respond in two ways. First, companies may change their real economic activity. For example, a rise in tax rates may create disincentives for investment and effort, or it may induce firms to move part of their activity to other jurisdictions with lower taxes, or even to relocate entirely. Second, higher tax rates may increase incentives to engage in tax planning in order to legally avoid or even illegally evade taxes by shifting or hiding book profits. The change in the tax base and thus in tax revenues is determined by the sum of both adjustment channels.

In this paper, we focus on local business taxation, where each municipality is free to choose its own tax rate. Although neglected in the literature, local business taxes warrant attention for several reasons. First, municipalities compete for the local tax base. Local tax competition may be expected to be fiercer than the more often studied international tax competition because the barriers for reallocation of business activities are considerably lower within a country, where the language, legal framework, and culture are the same and reallocation distances may be minimal. Second, in Germany, the country analyzed in this paper, the definition of the local business tax (LBT) base is the same in all municipalities, e.g., with respect to depreciation rules, deductibility of financing expenses and research expenditures. Divergent tax base definitions typically create empirical issues in multinational settings. At the same time, local business taxes provide substantial variation in tax rates, which facilitates empirical identification of the effects. In Germany, there are about 12,000 municipalities with varying LBT rates which also change over time. Third, there is an ongoing debate on reforming the federal structure of municipality financing and the fiscal equalization scheme in Germany as well as in other countries.

Therefore, we estimate the elasticity of the LBT base with respect to the LBT rate. The elasticity of the tax base comprises both, adjustments in real and book profits. This elasticity 
determines the extent to which a tax cut will be self-financed through an increase of the tax base and is thus of great importance in forecasting changes in tax revenues induced by tax reforms.

Furthermore, the inefficiency of taxation depends on the tax rate elasticity as well. In the context of local business taxation, a large elasticity in absolute terms indicates that at least one of two adjustment reactions are strong, both of which create externalities. The first reaction is that firms respond to a tax rate cut by shifting real or book profits to the low tax municipality, away from other jurisdictions. This implies horizontal externalities, because the local jurisdiction does not consider the change in other jurisdictions' tax revenues in its optimization. The second adjustment is that firms reduce their real economic activity or overall book profits when the tax rate increases. This implies vertical externalities, because the optimizing municipality does not internalize effects on higher level tiers of government, for example, a loss in corporate tax revenues on the national level as a result of an increase in the LBT rate.

The new tax responsiveness literature (e.g., Feldstein, 1995; Gruber and Saez, 2002) advances similar arguments for focusing on the elasticity of the tax base with respect to the tax rate, encompassing adjustments of all real economic activities as well as tax avoidance and evasion reactions of the taxpayers. While this literature focusses on personal income taxation, the arguments are also valid for the analysis of local business taxes addressed in this paper.

In the context of local business taxation, an additional motivation for estimating the elasticity of the tax base is that this elasticity determines the strength of the incentive effects induced by federal fiscal equalization schemes, which use the local taxing power as indicated by the local tax base to determine the size of financial transfers (Buettner, 2006; Egger et al., 2010). In Germany, the fiscal equalization scheme mitigates the local tax competition for the LBT base. For example, when a municipality increases its LBT rate, the LBT base is expected to decrease - the elasticity to be estimated here describes the extent of this adjustment. This 
diminishes the taxing power of the jurisdiction, which entitles it to receive higher financial transfers. The fiscal equalization scheme thus makes setting higher tax rates more attractive for a municipality, as the equalization partly compensates the municipality for the loss in the tax base. Ideally, the horizontal externality of taxation would be internalized. We demonstrate that the German local fiscal equalization scheme may explain why LBT rates have not been pushed down by tax competition in Germany, very much in contrast to the corporate tax rate in Germany and in most other European and OECD countries in the context of increasing globalization.

Very few attempts exist in the literature to estimate the responsiveness of business profits with respect to corporate or other business tax rates, despite its importance for welfare analysis and for policy making. Clausing (2007), Devereux (2007), and Katsimi and Sarantides (2012) rely on country-level tax revenue data from OECD countries. It remains an open question if such cross-country studies can control sufficiently for differences between countries, such as differences in the definition of the corporate tax base and in other laws, institutions and cultural influences relevant for firms, which may also change over time in parallel to changes in tax rates. In particular, due to the very limited within-country variation in statutory tax rates at the country level, tax effects are typically not identified in these studies if country-fixed effects are taken into account (see Devereux, 2007).

Buettner (2005) partly overcomes these problems by using a panel of municipalities in the German federal state of Baden-Wuerttemberg and exploiting variations in LBT rates. However, he only has access to tax revenue data. This is problematic because in a given period, tax revenues generally differ from the taxes finally due for the same period, especially in the case of business taxes. In contrast, tax return data, as we use in this paper, contain the required information on assessed taxes. As we demonstrate in section 5.4, this issue may explain why Buettner (2005) obtains a very large point estimate of the elasticity of the LBT base with respect to the LBT rate of -1.34 . 
Moving to the analysis of firm-level micro data, Gruber and Rauh (2007) use a sample of financial statements from Compustat, which contains mainly large corporations in the US, and estimate an elasticity of the corporate income tax (CIT) base with respect to the net-of-tax marginal CIT rate of 0.2. In contrast, we use administrative tax return data on the universe of firms in Germany, including small and medium sized and unincorporated businesses. Dwenger and Steiner (2012) construct a pseudo-panel from CIT return files in Germany by aggregating the data to the level of industries and federal states. They exploit variation in effective CIT rates, which is mainly due to differences in the amounts of losses carried forward, and estimate an elasticity of the CIT base with respect to the average corporate tax rate of -0.5. By analyzing the CIT, their analysis is confined to predominantly large corporations. Furthermore, it is possible that local business profits respond more strongly to LBT rates than national corporate profits to nation-wide corporate tax rates, because reallocation of business activity from one municipality to the other within the same country may be less costly than international reallocation, as mentioned above. Therefore, the lack of an estimate of the responsiveness of local business profits to LBT rates based on firm-level tax return data is an important omission in the literature.

Other articles analyze more specific effects of the LBT. Becker et al. (2012) consider the effect on the location decision of foreign multinational enterprises in Germany, and Buettner et al. (2011) analyze the effect on the strategic formation of consolidated tax groups. For policymakers interested in tax revenues, the sum of these and any further effects influencing taxable local profits is relevant, which is captured by the elasticity of the LBT base.

For our analysis, we use the universe of administrative German LBT return files including almost one million firms with positive tax liabilities observed in 2001 and 2004 . We estimate the tax rate elasticity of the LBT base using a multivariate IV regression after eliminating municipality fixed effects. To account for the endogeneity of the firm-specific effective average tax rates, we use lagged municipality-specific statutory LBT rates as 
instruments. Thus, we use the heterogeneity of statutory tax rates and their changes over time to identify the effect of taxation.

In the following section 2, we describe the German LBT as a source of tax rate variation. Section 3 introduces the administrative firm-level tax return data, and section 4 describes our empirical methodology. Our estimation results are presented in section 5. We include an analysis of heterogeneous effects and compare our results with those from the literature, discussing the implications of using tax return versus tax revenue data. We also assess the effects of the fiscal equalization scheme. Section 6 concludes the analysis.

\section{The German local business tax as a source of tax rate variation}

All companies, corporations as well as unincorporated firms, are subject to the LBT in Germany. The tax base is determined in the same way all over Germany, because the rules are set by federal laws. The tax is mainly a tax on business profits. Some additions and reductions apply; most notably, in the period covered by our analysis, 2001-2004, half of the interest expenses on long-term debt were added back to the tax base. The LBT is determined in two steps. In the first step, a basic tax rate that is uniform nation-wide is applied in order to obtain the uniform basic tax. For corporations, a flat uniform basic tax rate of 5\% was applied in the period of analysis. Unincorporated firms benefitted from a tax free allowance of $€ 24,500$ (US\$ 33,428 on December 31, 2004). For exceeding income, they faced a progressive schedule with increasing marginal uniform basic tax rates of $1 \%, 2 \%, 3 \%$, and $4 \%$, in four successive tax brackets of width $€ 12,000$ (\$16,373) each, and 5\% for income exceeding $€ 72,500$ (\$98,919). Subsequently, the uniform basic tax of companies operating in more than one municipalities is allocated to the municipalities involved by formula apportionment, which is usually based on the payroll attributable to the subsidiaries.

In the second step, the municipalities apply a tax rate multiplier, which they are entitled to determine within certain limits, to their allocated share of the uniform basic tax. In 2004, a 
legal minimum multiplier of 200 percent was introduced, this was chosen by 134 municipalities. The average multiplier was 385 percent in 2001 and 388 percent in 2004 (Federal Statistical Office, 2005), with top multipliers reaching about 500 percent in both years. Figure 1 in the Appendix shows the distribution of the LBT multipliers in 2004. Thus, importantly for this analysis, the municipalities are free to choose the statutory LBT rate and change it anytime. Taking into account the progressive schedule for unincorporated firms, as well as the deductibility of the LBT from its own tax base as a business expense, the $5^{\text {th }}$ and $95^{\text {th }}$ percentiles of the average LBT rates effective for firms with strictly positive tax liabilities in 2001 and 2004 were $0.3 \%$ and $18.2 \%$ (see section 3).

The part of the variation in the effective average LBT rates stemming from the allowance and the progressivity of the tax code for unincorporated firms is endogenous in the tax base equation, because the profits of the firm determine the applicable tax bracket. In contrast, the variation due to different tax multipliers in the more than 12,000 municipalities in Germany and their changes over time can be used to identify the tax effects, as we discuss in section 4 . Comparing 2001 and 2004, 2652 municipalities increased their LBT multipliers (by 22 basis points on average, conditional on a positive increase), but only 254 municipalities decreased their multipliers (by 24.3 basis points on average), reflecting a trend towards higher LBT rates.

In addition to the LBT, corporations are subject to the corporate income tax (CIT) levied at the national level at a flat tax rate of $25 \%$ in the period under consideration. The tax base of the CIT is business profits and similar to the tax base of the LBT. Shareholders of unincorporated businesses pay a progressive personal income tax on their share of business profits, levied at the national level as well. In the period of this analysis, shareholders of unincorporated firms could credit 1.8 times the uniform basic tax against their personalincome-tax liability as long as this lump-sum amount did not exceed the personal income tax they had to pay for the corresponding business income. 
In the 1990s and 2000s, LBT rates exhibited an increasing trend (see Figure 2 in the Appendix for the average multiplier over all municipalities in Germany). This trend stands in sharp contrast to the German CIT rate, which was decreased significantly multiple times within the same time period from 50\% for retained earnings in 1993 down to $15 \%$ since 2008, and in contrast to the trend of national CIT rates in most European and OECD countries. The literature commonly explains the decreasing trend in CIT rates by accelerating tax competition for increasingly mobile capital due to the intensifying globalization (e.g. Devereux et al., 2008). ${ }^{1}$ Without further information, a tempting explanation for the opposing trend of the LBT rates could have been that the tax base were less elastic with respect to the LBT rate than with respect to the CIT rate, such that tax competition would be less relevant for the LBT. However, in this paper we empirically show that the elasticities with respect to the two tax rates are similar (section 5.1). Instead, we provide evidence suggesting that the differing trends are explained by the fiscal equalization scheme for German municipalities, which largely compensates municipalities for the loss in the tax base when they increase the LBT rate (section 5.4). Thus, the equalization scheme increases incentives for municipalities to raise local business taxes and mitigates tax competition for the local tax base.

\section{Administrative firm-level tax return and municipality data}

For our analysis, we use the universe of administrative individual tax return files for the German LBT for 2001 and 2004. The data are provided by the Research Data Centers of the Federal and State Statistical Offices once in three years. The data contain all information necessary to calculate the LBT liability of a firm, e.g., profits, long term interest expenses, the asserted value of the firm's real estate, and the final assessed LBT base. Furthermore, the records report the municipality, the legal form and the industry of a firm. An advantage of the

\footnotetext{
${ }^{1}$ Onaran et al. (2012) report that globalization has increased implicit labor income tax rates, but has had no effect on implicit tax rates on capital income in the EU15.
} 
common nation-wide statistic is that no issues of comparability arise, which plague crosscountry studies of taxation effects. A disadvantage is that due to strict data protection laws, firm identifiers are unavailable, so we cannot construct firm-level panel data from the two cross-sections.

We merge the data with official information about all German municipalities in these two years, which are provided by the Statistical Offices as well. These data inform about a municipality’s LBT multiplier, population size and structure, and the economic use of its area. We link the two data sources using information about a company's location, which is available in the tax return files.

To estimate the tax rate elasticity of the tax base, we only include firms with a strictly positive tax liability in the estimation sample. Firms that do not pay taxes because they make losses or because they are unincorporated and their profits are below the tax allowance are not included in the estimation sample. This leaves us with 901,520 firms in 2001 and 937,056 firms in 2004. To account for possible non-random sample selection, in the estimations we control for the share of firms with a strictly positive tax liability in the firm's municipality. 
Table 1: Variable descriptions and descriptive statistics

\begin{tabular}{|c|c|c|c|c|c|c|}
\hline & \multirow[b]{2}{*}{ Mean } & \multirow[b]{2}{*}{ Sd dev. } & \multicolumn{3}{|c|}{ Percentiles } & \multirow[b]{2}{*}{ Description } \\
\hline & & & $5 \%$ & Median & $95 \%$ & \\
\hline \multicolumn{7}{|c|}{ Firm-level tax return data: } \\
\hline tax base & 70635 & 99518 & 4709 & 42254 & 220804 & Gross local business tax base in euro \\
\hline tax rate & 0.0660 & 0.0627 & 0.0026 & 0.0377 & 0.1820 & Effective average local business tax rate \\
\hline real estate & 3.3589 & 54.1556 & 0.0000 & 0.0000 & 12.6161 & Asserted value of real estate in $€ 10,000$ \\
\hline firms in municip. & 9969 & 22206 & 63 & 1075 & 67493 & Number of firms in municipality \\
\hline sole proprietorship & 0.6411 & & & & & Legal form: sole proprietorship (base cat.) \\
\hline partnership & 0.1196 & & & & & Legal form: partnership \\
\hline corporation & 0.2393 & & & & & Legal form: corporation \\
\hline multi-municipal firm & 0.0001 & & & & & Tax is split over several municipalities \\
\hline tax group & 0.0017 & & & & & Group with consolidated tax filing status \\
\hline share with pos. tax & 0.4912 & 0.0931 & 0.3183 & 0.5011 & 0.6224 & Share of firms in municip. with pos. tax \\
\hline year 2001 & 0.4903 & & & & & Observation in 2001 (base cat.) \\
\hline year 2004 & 0.5097 & & & & & Observation in 2004 \\
\hline industry 1 & 0.0156 & & & & & Agriculture, forestry, and fishery (base cat.) \\
\hline industry 2 & 0.0010 & & & & & Mining and quarrying \\
\hline industry 3 & 0.0598 & & & & & Manuf. of intermed. / non-durable goods \\
\hline industry 4 & 0.0686 & & & & & Manuf. of investment / durable goods \\
\hline industry 5 & 0.0027 & & & & & Electricity, gas, and water supply \\
\hline industry 6 & 0.1337 & & & & & Construction \\
\hline industry 7 & 0.2621 & & & & & Trade, maintenance, and repair \\
\hline industry 8 & 0.0640 & & & & & Hotels and restaurants \\
\hline industry 9 & 0.0507 & & & & & Transport, storage, and communication \\
\hline industry 10 & 0.0619 & & & & & Financial intermediation \\
\hline industry 11 & 0.0553 & & & & & Real estate and renting \\
\hline industry 12 & 0.1442 & & & & & Business service activities \\
\hline industry 13 & 0.0804 & & & & & Public and personal service activities \\
\hline federal states 1 & 0.2365 & & & & & North Rhine-Westfalia (base cat.) \\
\hline federal states 2 & 0.0365 & & & & & Schleswig-Holstein \\
\hline federal states 3 & 0.0931 & & & & & Lower Saxony \\
\hline federal states 4 & 0.0815 & & & & & Hesse \\
\hline federal states 5 & 0.0646 & & & & & Rhineland-Palatinate or Saarland \\
\hline federal states 6 & 0.1393 & & & & & Baden-Wuerttemberg \\
\hline federal states 7 & 0.1863 & & & & & Bavaria \\
\hline federal states 8 & 0.0087 & & & & & Brandenburg \\
\hline federal states 9 & 0.0144 & & & & & Mecklenburg-West Pomerania \\
\hline federal states 10 & 0.0350 & & & & & Saxony \\
\hline federal states 11 & 0.0188 & & & & & Saxony-Anhalt \\
\hline federal states 12 & 0.0202 & & & & & Thuringia \\
\hline federal states 13 & 0.0651 & & & & & Berlin, Hamburg, or Bremen (city states) \\
\hline \multicolumn{7}{|c|}{ Merged municipal data: } \\
\hline population & 274095 & 656145 & 1852 & 28435 & 1726363 & Population size \\
\hline youths share & 0.1518 & 0.0251 & 0.1107 & 0.1515 & 0.1942 & Share of population below 16 years of age \\
\hline elderly share & 0.2437 & 0.0309 & 0.1938 & 0.2425 & 0.2930 & Share of population above 64 years of age \\
\hline area size & 137.0 & 190.6 & 10.7 & 71.9 & 755.2 & Size of municipality in hectares \\
\hline recreational area & 828.4 & 2023.3 & 5.0 & 78.0 & 5702.0 & Recreational area in ha \\
\hline street area & 1235.6 & 2104.8 & 52.0 & 420.0 & 7131.0 & Area used for streets, paths, squares in ha \\
\hline agricultural area & 4073.9 & 3921.2 & 437.0 & 3070.0 & 11610.0 & Agricultural area in ha \\
\hline Firm-year obs. & 1838576 & & & & & \\
\hline
\end{tabular}


Table 1 reports descriptive statistics of the variables used in this analysis in the pooled estimation sample of observations from 2001 and 2004. The dependent variable, the LBT base, has a mean of $€ 70.635$ (US\$96.346 on December 31, 2004). This highlights the high number of small and medium sized firms and demonstrates the advantage of our data in comparison to collections of listed corporations, which are often used in the literature, because these are limited to large corporations and therefore very selective. The effective average LBT rate over all firms has a mean of $6.6 \%$. Again, this indicates that a high share of the firms are unincorporated and small and benefit from the progressive tax rate structure. The median firm in our sample is located in a municipality with 1,075 firms, while the average is 9,969, which reflects the skewed distribution of municipality size. $64 \%$ of the firms are sole proprietorships. Only $0.01 \%$ have operations in more than one municipality and are subject to formula apportionment. No more than $0.17 \%$ of the observations in the sample represent a consolidated tax group. The most frequent industry category is trade, maintenance and repair, followed by business service activities and construction. The largest federal states in Germany in terms of area and population, North Rhine-Westfalia and Bavaria, also host the largest numbers of firms in our sample. The median firm is located in a municipality with 28,000 inhabitants, but the average across firms is 274,000, again reflecting the skewed distribution. The shares of youths and elderly vary notably across municipalities, as indicated by the percentiles.

\section{Empirical methodology}

Using the pooled cross-sections of individual firm-level data, we estimate the tax rate elasticity of the LBT base using the following log-log equation:

$$
\ln \left(y_{i m t}\right)=\beta_{0}+\beta_{1} \ln \left(\tau_{i m t}\right)+\sum_{k=2}^{K} \beta_{k} x_{k, i m t}+u_{i}+v_{m}+w_{t}+\varepsilon_{i m t},
$$


where the indices $i, m$, and $t$ refer to firms, municipalities, and observation years, respectively. The tax base is denoted by $y$, the tax rate by $\tau$, and $x_{k}$ are control variables. In the model we distinguish between unobserved firm effects $u$, municipality effects $v$, and time effects $w$. The remaining error term is denoted $\varepsilon$. Among the coefficients $\beta$ to be estimated, $\beta_{1}$ is the elasticity of the tax base with respect to the tax rate, which is of primary interest.

We use the ratio tax payment / tax base as a backward-looking measure of the effective average tax rate $\tau$ (cf. Fullerton, 1984; Devereux, 2004; Gordon et al., 2004). This avoids making assumptions about future investment plans, which is necessary to calculate forwardlooking measures. A main motivation for using forward-looking measures of effective tax rates is to account for differences in the definition of tax bases in cross-country analyses. This is not relevant here, because the definition of the tax base is the same in all municipalities and does not change in the observation period. Our measure of the effective average tax rate exclusively captures the tax multipliers set by the municipalities and the progressive tax schedule for unincorporated businesses, not the rules for determining the tax base, which are the same for all observations.

Furthermore, we use the effective average tax rate rather than the effective marginal tax rate. The response of the LBT base to the LBT rate we are interested in is the result of both, extensive adjustments such as location decisions of firms, as well as intensive adjustments such as marginal investments. In theory, average tax rates should be more relevant for the former and marginal tax rates for the latter type of adjustments. We choose effective average tax rates for our analysis because extensive adjustments may result in larger changes in the local tax base and may thus dominate the total effect. However, the distinction between average and marginal tax rates is not very important in our setting because average and marginal LBT rates are identical for corporations and approximately identical for unincorporated firms with large profits. 
To account for municipality fixed effects such as the location and local infrastructure not changing between 2001 and 2004, we transform the data by subtracting the municipality means of all variables in 2001 from the corresponding variables in 2004. Since the mean of the municipality fixed effect $v_{m}$ over all firms in municipality $m$ equals $v_{m}$, this transformation eliminates the municipality fixed effect. This procedure leaves us with only one transformed cross-section for the estimation. An estimating of equation (1) by OLS would be expected to be biased because of the omission of the municipality effects $v_{m}$, which are likely to be correlated with the tax rates as well as with firm profits.

Even after the data transformation, an OLS estimation will be biased because of the endogeneity of the tax rate. The dependent variable, the tax base $y$, determines the tax bracket applicable to an unincorporated firm, and thus its effective average tax rate. We account for this type of endogeneity by treating the tax rate as endogenous and using the first and second lags of the statutory tax rate of the firm's municipality as excluded instrument. We define the statutory tax rate as the effective proportional tax rate applicable to a corporation, taking into account the uniform basic tax rate of 5\%, the deductibility of the LBT from its own tax base as a business expense, and the municipality's tax multiplier. ${ }^{2}$ Thus, variation in the statutory tax rate exclusively comes from variation in multipliers across municipalities and time. Endogenous variation stemming from the firm level due to the tax allowance and the tax progressiveness for unincorporated firms is excluded. Since the LBT is proportional for corporations, their marginal, average and statutory tax rates defined in this sense are equal, and the endogeneity problem does not arise. For unincorporated firms, the marginal and average tax rates approach the statutory tax rate, defined in this way, for large profits, when the tax allowance and the progressive tax rates for small profits become negligible. For

\footnotetext{
${ }^{2}$ Because of the deductibility of the local business tax as a business expense, the local business tax is calculated as tax $=0.05$ (tax base $-\operatorname{tax}$ ) multiplier/100. Rearranging this equation, we get the tax rate $=\operatorname{tax} /$ tax base $=$ 0.05 multiplier / $(100+0.05$ multiplier). This is our formal definition of the statutory tax rate.
} 
unincorporated firms with small profits, there is still a (positive) correlation between the effective average tax rate and the statutory tax rate, which is what the IV approach requires.

The statutory tax rate is expected to be exogenous to an individual firm, which would render it a valid instrument. However, one might argue that municipalities may adjust their tax multipliers as a reaction to changing profits of the firms in the municipality. Therefore, we use the first and second lags of the statutory tax rates as instruments instead of the contemporaneous statutory tax rate. ${ }^{3}$ Since the statutory tax rate, which does not differ between firms within a municipality, is uncorrelated with the unobserved individual firm effects after eliminating the unobserved municipality effects by the data transformation, the omission of the unobserved firm effects is not expected to create a bias in the coefficient of the tax rate in the IV estimation either.

We control for the following firm characteristics: The asserted value of the firm's real estate as an indicator of firm size (the tax return data do not provide other indicators of size such as sales or the number of employees), a dummy variable indicating whether the firm is active in more than one municipality, an interaction term between these two variables, the legal form (dummies for partnership or corporation, where sole proprietorship is the omitted base category), and a dummy indicating whether the observation represents a group with consolidated tax filing status. Furthermore, we account for municipality characteristics. From the universe of the LBT files, we include the share of firms with strictly positive tax liability in each municipality, in order to control for non-random selection into the estimation sample which, as mentioned above, only includes such firms. From the municipality statistics, we include the log population size and the population structure (shares of persons below 16 and above 64 years of age); these characteristics may change over time and may thus not be

\footnotetext{
3 We use the lags of $t-1$ and $t-2$ as instruments; using lags further behind would lead to a weakinstrumentproblem, as indicated by weak instruments tests. As we subtract the municipality means of all variables from $t-3$ in the data transformation to eliminate the municipality fixed effects, it still cannot be ruled out entirely that the lagged instruments may be correlated with the transformed error term, if municipalities change their multipliers in reaction to changes in business profits; however, we expect this potential correlation to be negligible.
} 
captured by the municipality fixed effects. We further control for the area size of a municipality, which may change over time as a result of administrative reforms, and the area sizes used for different purposes (for recreation; streets, paths and squares; and for agriculture); shifts in the usage of area may indicate changing priorities in the municipality or structural change. In OLS and IV estimations not eliminating the municipality effects, which we present for comparison, we further include a time dummy variable for 2004 to control for a time fixed effect, such as the business cycle, in the pooled cross sectional data from 2001 and 2004. We report standard errors robust to heteroskedasticity and clustering at the municipal level throughout.

\section{Estimation results}

\subsection{Main results}

The first column of Table 2 presents the main results from the IV estimation of equation (1) after the data transformation that eliminates the unobserved municipality effects. The consistently estimated elasticity of the LBT base with respect to the LBT rate is -0.45 and significant at the 1\%-level. Thus, when a municipality increases its LBT rate by one percent, the firms active in the municipality reduce their local taxable profits by almost half a percent. Considering that the LBT is proportional for corporations and nearly proportional for unincorporated firms with large profits as well, one can infer that tax revenues increase by about 1-0.45 $=0.55$ percent when the tax rate is increased by one percent. This is consistent with the increasing side of the Laffer curve, where tax revenues rise when the tax rate is increased, but clearly less than proportionally. 
Table 2: Main tax responsiveness regressions (all firms)

\begin{tabular}{|c|c|c|c|c|}
\hline & \multirow{2}{*}{$\begin{array}{l}\text { Consistent } \\
\text { estimation } \\
\text { IV } \\
\end{array}$} & \multicolumn{3}{|c|}{ For comparison: Inconsistent estimations } \\
\hline & & IV & OLS & OLS \\
\hline Elimination of municipality effects & yes & no & yes & no \\
\hline Federal state dummies & no & yes & no & yes \\
\hline Industry dummies & yes & yes & yes & yes \\
\hline $\log$ tax rate & $\begin{array}{l}-0.4456 * * * \\
(0.1142)\end{array}$ & $\begin{array}{l}-0.0747 \\
(0.0466)\end{array}$ & $\begin{array}{l}0.3930 * * * \\
(0.0023)\end{array}$ & $\begin{array}{l}0.4131 * * * \\
(0.0011)\end{array}$ \\
\hline real estate & $\begin{array}{l}0.0012^{* * *} \\
(0.0003)\end{array}$ & $\begin{array}{l}0.0012^{* * *} \\
(0.0003)\end{array}$ & $\begin{array}{l}0.0008^{* * *} \\
(0.0002)\end{array}$ & $\begin{array}{l}0.0009 * * * \\
(0.0002)\end{array}$ \\
\hline realestate * multi-municipal firm & $\begin{array}{l}-0.0010^{* *} \\
(0.0005)\end{array}$ & $\begin{array}{l}0.0036^{*} \\
(0.0020)\end{array}$ & $\begin{array}{l}-0.0000 \\
(0.0006)\end{array}$ & $\begin{array}{l}0.0027 \\
(0.0020)\end{array}$ \\
\hline log firms in municipality & $\begin{array}{l}-0.3017 * * * \\
(0.0523)\end{array}$ & $\begin{array}{l}0.0759 * * * \\
(0.0230)\end{array}$ & $\begin{array}{l}-0.2380 * * * \\
(0.0695)\end{array}$ & $\begin{array}{l}0.0457 * * \\
(0.0200)\end{array}$ \\
\hline partnership & $\begin{array}{l}0.7785^{* * *} \\
(0.0793)\end{array}$ & $\begin{array}{l}0.4766^{* * *} \\
(0.0314)\end{array}$ & $\begin{array}{l}0.2033^{* * *} \\
(0.0051)\end{array}$ & $\begin{array}{l}0.1495^{* * *} \\
(0.0040)\end{array}$ \\
\hline corporation & $\begin{array}{l}0.0312 \\
(0.2398)\end{array}$ & $\begin{array}{l}-0.8133^{* * *} \\
(0.1011)\end{array}$ & $\begin{array}{l}-1.7274 * * * \\
(0.0127)\end{array}$ & $\begin{array}{l}-1.8536 * * * \\
(0.0089)\end{array}$ \\
\hline multi-municipal firm & $\begin{array}{l}1.4086^{* * *} \\
(0.1601)\end{array}$ & $\begin{array}{l}0.4589 * * * \\
(0.0864)\end{array}$ & $\begin{array}{l}2.0009 * * * \\
(0.1900)\end{array}$ & $\begin{array}{l}0.2855^{* * *} \\
(0.0768)\end{array}$ \\
\hline tax group & $\begin{array}{l}1.7070 * * * \\
(0.0547)\end{array}$ & $\begin{array}{l}1.5420 * * * \\
(0.0345)\end{array}$ & $\begin{array}{l}1.4902 * * * \\
(0.0414)\end{array}$ & $\begin{array}{l}1.3845^{* * *} \\
(0.0321)\end{array}$ \\
\hline share with pos. tax & $\begin{array}{l}0.0144 \\
(0.0653)\end{array}$ & $\begin{array}{l}0.2884 * * * \\
(0.0298)\end{array}$ & $\begin{array}{l}0.2970 * * * \\
(0.0689)\end{array}$ & $\begin{array}{l}0.1817^{* * *} \\
(0.0260)\end{array}$ \\
\hline log population & $\begin{array}{l}-0.5981^{* * *} \\
(0.1880)\end{array}$ & $\begin{array}{l}-0.0548^{* *} \\
(0.0213)\end{array}$ & $\begin{array}{l}-0.8605 * * * \\
(0.2602)\end{array}$ & $\begin{array}{l}-0.0521^{* *} \\
(0.0203)\end{array}$ \\
\hline youths share & $\begin{array}{l}-8.0822 * * * \\
(0.8922)\end{array}$ & $\begin{array}{l}-0.0944 \\
(0.1176)\end{array}$ & $\begin{array}{l}-12.3694 * * * \\
(0.9831)\end{array}$ & $\begin{array}{l}0.0799 \\
(0.1250)\end{array}$ \\
\hline elderly share & $\begin{array}{l}3.7586 * * * \\
(0.7726)\end{array}$ & $\begin{array}{l}-0.3995 * * * \\
(0.0840)\end{array}$ & $\begin{array}{l}5.0496 * * * \\
(1.0471)\end{array}$ & $\begin{array}{l}-0.2733^{* * *} \\
(0.0856)\end{array}$ \\
\hline area size & $\begin{array}{l}0.0005 \\
(0.0016)\end{array}$ & $\begin{array}{l}-0.0002^{* *} \\
(0.0001)\end{array}$ & $\begin{array}{l}0.0011 \\
(0.0024)\end{array}$ & $\begin{array}{l}0.0000 \\
(0.0001)\end{array}$ \\
\hline recreational area & $\begin{array}{l}0.0003^{* * *} \\
(0.0001)\end{array}$ & $\begin{array}{l}-0.0000 \\
(0.0000)\end{array}$ & $\begin{array}{l}0.0004^{* * *} \\
(0.0001)\end{array}$ & $\begin{array}{l}0.0000 \\
(0.0000)\end{array}$ \\
\hline street area & $\begin{array}{l}-0.0000 \\
(0.0000)\end{array}$ & $\begin{array}{l}0.0000 \\
(0.0000)\end{array}$ & $\begin{array}{l}-0.0000 \\
(0.0001)\end{array}$ & $\begin{array}{l}-0.0000^{*} \\
(0.0000)\end{array}$ \\
\hline agricultural area & $\begin{array}{l}0.0001^{* * *} \\
(0.0000)\end{array}$ & $\begin{array}{l}0.0000 \\
(0.0000)\end{array}$ & $\begin{array}{l}0.0001^{* * *} \\
(0.0000)\end{array}$ & $\begin{array}{l}-0.0000 \\
(0.0000)\end{array}$ \\
\hline year 2004 & & $\begin{array}{l}0.0361^{* * *} \\
(0.0032)\end{array}$ & & \\
\hline constant & $\begin{array}{l}0.4830 * * * \\
(0.0255)\end{array}$ & $\begin{array}{l}10.4604^{* * *} \\
(0.1843)\end{array}$ & $\begin{array}{l}0.3262 * * * \\
(0.0215)\end{array}$ & $\begin{array}{l}12.6260 * * * \\
(0.0634)\end{array}$ \\
\hline First stage $F$-statistic of excl. IV & 56.620 & 731.173 & & \\
\hline Hansen’ s $J \chi^{2}$ & 0.062 & 0.000 & & \\
\hline Hansen’ s $J$ p-value & 0.803 & 0.998 & & \\
\hline Endogeneity test $\chi^{2}$ & 20.547 & 102.273 & & \\
\hline Endogeneity test $p$-value & 0.000 & 0.000 & & \\
\hline $\mathrm{N}$ & 922381 & 1775049 & 922662 & 1838576 \\
\hline
\end{tabular}

Notes: The dependent variable is the log tax base. Where indicated, municipality fixed effects are eliminated by a data transformation where the municipality mean in year $t-1$ in subtracted from all variables. In the IV estimations, the log tax rate is treated as endogenous, and the second and third lags of the statutory tax rate in the municipality are used as excluded instruments. Standard errors are robust to heteroskedasticity and clustering by municipality (across years). Stars (***/**/*) indicate significance at the 1\%/5\%/10\% level. Source: Local business tax statistics and municipality data for 2001 and 2004 from the Statistical Offices. 
The F-statistic of joint significance of the excluded instruments in the first stage is 56.6, indicating that the instruments are strong. Hansen's over-identification test yields a $p$-value of above $80 \%$ and thus does not indicate a violation of the exogeneity assumption. The endogeneity test clearly confirms endogeneity of the tax rate and the necessity of IV estimation.

To gauge the importance of accounting for the endogeneity of the tax rate and unobserved municipality effects in the econometric estimation, in the other three columns we report results from naïve estimators that we expect to be inconsistent. An IV estimation without the data transformation using the cross-sections of 2001 and 2004 leads to a less negative point estimate, indicating that failure to account for unobserved municipality effects leads to an upward bias, even though we control for federal state dummies instead here. This is intuitive, because municipalities with large LBT rates tend to be attractive business locations (examples include Munich, Hamburg, and Frankfurt), which host profitable firms. This positive correlation between high profits and high tax rates biases the estimated coefficient of the tax rate upward. The causal effect of the tax rate on profits can only be identified when appropriately isolating it from the unobserved effects of the municipality. The IV estimation alone is insufficient, because the instruments, lagged statutory tax rates, are fully exogenous only when the unobserved municipality effects are eliminated from the error term.

The two right-most columns show results from OLS estimations with and without the data transformation to eliminate the municipality effects. Here, we find an even stronger upward bias of the estimated coefficients, such that these become significantly positive. This bias is explained by the fact that for unincorporated firms, which face a progressive tax schedule, the tax base determines the tax bracket they fall into and thus the tax rate that is applied. Higher profits shift firms into brackets with higher tax rates, leading to a positive correlation. Treating the effective average tax rate as endogenous and using lagged statutory 
tax rates as instruments ensures that only the exogenous variation in the tax rates on the level of the municipalities is used for identification.

\subsection{Heterogeneity in tax responsiveness}

In this section we explore if the tax rate elasticity of the tax base differs by legal form, sector, or firm size. We split the data by these criteria and run our preferred IV estimator with eliminated municipality fixed effects on the sub-samples. The results appear in Table 3 . We include the same control variables as before, but only report the elasticity of interest. We first report the results and discuss them jointly below.

Table 3: Tax responsiveness of sub-groups of firms

\begin{tabular}{llllll}
\hline \hline & $\begin{array}{l}\text { Coefficient } \\
\text { of log tax } \\
\text { rate }\end{array}$ & Std err. & $\begin{array}{l}\text { First stage } \\
\text { F-statistic of } \\
\text { excl. IV }\end{array}$ & $\begin{array}{l}\text { Hansen's } J \\
p \text {-value }\end{array}$ & N \\
\hline Unincorporated firms & $-0.7047^{* * *}$ & $(0.1663)$ & 51.328 & 0.133 & 698979 \\
Corporations & 0.2243 & $(0.2195)$ & 388.254 & 0.318 & 222267 \\
Primary or secondary sector & $-0.1917^{*}$ & $(0.1051)$ & 38.851 & 0.080 & 255799 \\
Tertiary sector (services) & $-0.5426^{* * *}$ & $(0.1551)$ & 34.529 & 0.411 & 665672 \\
Larger firms & -0.1110 & $(0.1632)$ & 7.870 & 0.243 & 126464 \\
Smaller firms & $-0.4200^{* * *}$ & $(0.1217)$ & 51.910 & 0.762 & 794959 \\
\hline
\end{tabular}

Notes: The table shows the coefficient of the log tax rate from IV regressions with the log tax base as the dependent variable and including the same control variables as in Table 2, based on sub-samples as indicated in the first column. Municipality fixed effects are eliminated by a data transformation where the municipality mean in year $t-1$ in subtracted from all variables. The log tax rate is treated as endogenous, and the second and third lags of the statutory tax rate in the municipality are used as excluded instruments. Larger firms are those with above median real estate holdings, smaller firms below median. Standard errors are robust to heteroskedasticity and clustering by municipality (across years). Stars (***/**/*) indicate significance at the $1 \% / 5 \% / 10 \%$ level.

Source: Local business tax statistics and municipality data for 2001 and 2004 from the Statistical Offices.

Unincorporated firms, i.e., sole proprietorships and partnerships, exhibit a significantly stronger responsiveness to taxation than corporations, which do not significantly react to changes in LBT rates. While the tax base elasticity is significantly negative for all sectors, firms in the tertiary (services) sector respond more strongly than firms in the primary (agricultural) and secondary (manufacturing) sector. ${ }^{4}$ Finally, we use the value of a firm's real

\footnotetext{
${ }^{4}$ We combine the primary and secondary sectors because the agricultural sector is very small in Germany.
} 
estate as an indicator of firm size. As mentioned above, sales or employment figures are unavailable in our data, and we cannot use profits as an indicator of firm size, because they are endogenous in the tax base equation. Thus, we define smaller and larger firms as firms with a real estate value below or above the median. The results show that smaller firms exhibit a stronger reaction than larger firms, whose elasticity is insignificant. The first stage F-statistics indicates strong instruments except for the group of larger firms according to the real estate value. The null hypothesis of Hansen's over-identification test must be rejected at the $10 \%$-level in one of the six estimations concerning the primary and secondary sector ( $p$ value: $8 \%$ ). The estimations for these sectors and for large firms must therefore be interpreted with caution.

The finding that unincorporated firms respond more strongly to local business taxation than corporations is surprising, because unincorporated firms can partly credit their LBT liability against their personal income tax, in contrast to corporations (see section 2). Most of the unincorporated firms are sole proprietorships (Table 1), which are smaller than corporations in most cases. The effect of the legal form may thus reflect the effect of firm size. Similarly, service firms are often smaller than manufacturing companies, so the three sample splits deliver a consistent picture. A possible explanation why smaller firms react more strongly to taxation may be that their owner-managers use their direct influence to minimize their tax payment. In contrast, the hired management of larger corporations may be more alert to before-tax performance measures, especially if the shareholders are a diverse mix of personal, corporate and institutional shareholders from different countries with divergent tax incentives. These issues are almost unexplored in the extant literature, which mostly uses financial statement data from large corporations and ignores small, unincorporated firms.

The fact that for corporations, we do not find a significant response of the LBT base to the LBT rate, contrasts with the results of the micro data analyses of Gruber and Rauh (2007) 
for the USA and Dwenger and Steiner (2012) for Germany, which find significant elasticities of the CIT base with respect to the CIT rate. Apparently, corporations respond more strongly to corporate income taxes, whereas unincorporated firms respond to local business taxes. A possible explanation may be that corporations tend to operate more on a multinational level and base their multinational tax planning on a comparison of national CIT rates, whereas typically smaller, unincorporated firms operate more within a country and exploit LBT rate differences between municipalities for their tax planning.

\subsection{Tax return data versus tax revenue data}

Our estimated elasticity of the LBT base with respect to the LBT rate of -0.45 , which we obtain for the full sample, is substantially smaller in absolute terms than the only other estimate available for the LBT of -1.34 , which is reported by Buettner (2005). Buettner does not use micro data, but aggregated data on the municipality level for the German federal state of Baden-Wuerttemberg. To assess if the difference occurs due to the aggregation of the data, we aggregate our data to the level of the municipality as well. Specifically, we construct a pseudo-panel and ensure that each observation consists of at least 50 firms by further combining municipalities within the same county if at least one of the municipalities has less than 50 firms.

The analogue to the estimation approach we use for the micro data would be a combination of municipality fixed effects and IV estimation. However, with the aggregated data, tests of IV relevance indicate that our instruments, the lagged statutory LBT rates, become weak when using the fixed effects estimator. Therefore, we estimate IV regressions based on the pooled aggregated cross-sections. In the first column of Table 4, we use the same instruments as in the micro data estimations, i.e., the second and third lags of the statutory tax rates. However, here, the null hypothesis of the Hansen over-identification test is rejected, which presumably indicates endogeneity of the second lag in this setting, perhaps due to 
aggregation bias. Therefore, in the second column, we repeat the estimation only using the third lag as IV. In both columns, our point estimate of the elasticity becomes smaller in absolute terms, as it did before in our IV estimation without accounting for municipality effects (second column in Table 2), but here they are still significantly different from zero. Regarding the comparison with results reported by Buettner (2005), the important insight is that aggregation does not explain his substantially larger point estimate.

Table 4: Using tax return versus tax revenue data: Pseudo-panel evidence

\begin{tabular}{|c|c|c|c|}
\hline & \multicolumn{2}{|c|}{ Tax return data } & \multirow{2}{*}{$\begin{array}{l}\text { Tax revenue data } \\
\text { IV lags } 2,3\end{array}$} \\
\hline & IV lags 2, 3 & IV lag 3 & \\
\hline \multirow[t]{2}{*}{$\log$ tax rate } & $-0.0967 * *$ & $-0.1203^{* * *}$ & $-1.1275^{* * *}$ \\
\hline & $(0.0391)$ & $(0.0423)$ & $(0.2171)$ \\
\hline First stage $F$-stat. & 301.379 & 478.243 & 299.866 \\
\hline Hansen’ s $J \chi^{2}$ & 3.864 & & 0.645 \\
\hline Hansen's $J p$-value & 0.049 & & 0.422 \\
\hline Endog. test $\chi^{2}$ & 115.613 & 116.255 & 49.066 \\
\hline Endog. test $p$-value & 0.000 & 0.000 & 0.000 \\
\hline $\mathrm{N}$ & 6943 & 6944 & 6921 \\
\hline
\end{tabular}

Notes: Pseudo-panel IV regressions on the municipality level. The dependent variable is the log tax base, which in the first two columns is aggregated from the individual firms' tax liabilities, whereas it is calculated back from the aggregated municipality tax revenues in the third columns. The log tax rate is treated as endogenous, and the lags of the statutory tax rate in the municipality, which are indicated in the column header, are used as excluded instruments. The regressions include the same control variables as in Table 2. Standard errors are robust to heteroskedasticity and clustering by municipality (across years). Stars $(* * * / * * / *)$ indicate significance at the $1 \% / 5 \% / 10 \%$ level.

Source: Local business tax statistics and municipality data for 2001 and 2004 from the Statistical Offices.

Another candidate explanation of the differing results is the measure of the tax base. Since Buettner (2005) only has access to tax revenue data on the municipal level, he obtains his measure of the LBT base by dividing LBT revenues by the LBT rate. This may be problematic, because business tax revenues are usually not fully paid in the same year that they are assessed for. During the year, only approximate pre-payments are collected. Then the tax is assessed in the following year, usually leading to subsequent payments of taxes or tax refunds. In case of business taxes, corrections of tax payments often occur even years later. To assess the relevance of this issue, we construct a new measure of the tax base by dividing tax revenue data by tax rates on the municipal level, as in Buettner (2005). The third column 
shows that this procedure results in a large point estimate in absolute terms, very similar to the estimate of Buettner (2005). Thus, we conclude that using tax revenue data instead of the more appropriate tax return data leads to a significant bias in the estimated elasticity away from zero. This may be explained by the higher volatility of tax revenues in comparison to assessed taxes. Presumably, when the tax rate is increased, firms exaggerate when they report the reduction in their expected tax base for the coming year to the tax administration in order to push through lower pre-payments, leading to subsequent tax payments in the following year. This finding may have implications for a large number of cross-country analyses using aggregated tax revenue data, for example from the OECD tax revenue statistics. Calculating an approximate tax base from such data to estimate tax rate elasticities may lead to biased results.

\subsection{Fiscal equalization and the elasticity of municipalities' budgets}

To calculate how a German municipality's total budget changes when it adjusts its LBT rate, one has to take into account the fiscal equalization scheme (see, e.g., Buettner, 2005). For simplicity, in this section we treat the LBT as a proportional tax, which is exact for corporations and approximate for large unincorporated firms as well. Since these firms dominate total revenues, this simplification is appropriate here, where we are interested in total revenues. Then a municipality's total budget after fiscal equalization, $a$, can be written in a stylized way as

$$
a=t b-\alpha \bar{t} b+\beta \bar{t}(\bar{b}-b)+x .
$$

The effective LBT rate in the municipality is denoted $t$ and the LBT base is $b$, so $t b$ is the LBT revenue before fiscal equalization. The next two summands describe the fiscal equalization, where the first is the general contribution of the municipality to the equalization scheme (Umlage), and the second the key allocations it receives (Schlüsselzuweisungen). To calculate the general contribution, one applies the standardized LBT rate $\bar{t}$, which is the average rate in 
the federal state, to the municipality's tax base, and multiplies by a marginal compensation rate $\alpha$ set by the federal state for all municipalities. The key allocations are determined by applying the standardized rate $\bar{t}$ to the gap between the standardized LBT base $\bar{b}$, which is the average per capita tax base in the federal state multiplied by the population size, and the municipality's actual tax base. This gap reflects the under- or over performance of the municipality. The factor $\beta$ is another marginal compensation rate set by the federal state, which determines by how much these differences in performance are equalized. High marginal compensation rates $\alpha$ and $\beta$ imply a stronger fiscal equalization; if they are zero, there is no equalization at all. Finally, $x$ summarizes all other sources of a municipality's revenues that are unrelated to local business taxes.

From equation (2), the elasticity of a municipality's total budget with respect to the LBT rate is derived as

$$
\frac{d a}{d t} \frac{t}{a}=\frac{t b}{a}\left[1+\left(1-\frac{(\alpha+\beta) \bar{t}}{t}\right) \frac{d b}{d t} \frac{t}{b}\right]
$$

The term in square brackets is the elasticity of the LBT revenues after fiscal equalization, which differs from one plus the elasticity of the LBT base $\frac{d b}{d t} \frac{t}{b}$ due to the fiscal equalization scheme. This term must be multiplied by the share of LBT revenues (before equalization) in the municipality's total budget, $t b / a$, to obtain the elasticity of the total budget. To illustrate the effect of the equalization scheme, we compare Hesse, a federal state with a comparably weak fiscal equalization scheme, to North Rhine-Westphalia (NRW), a state with strong equalization. ${ }^{5}$ In each state, we consider a stylized municipality with the average share of LBT revenues in the total budget and the average LBT rate in their state, so $t$ and $\bar{t}$ are the same in these calculations.

\footnotetext{
${ }^{5}$ Reasons for the differences among the federal states may be differences in local administration and spatial structures, socio-economic characteristics, and preferences (Buettner et al., 2008, p. 91). Hesse implements minimum key allocations neglected in formula (2) for simplicity, which effectively increase equalization in this federal state as well.
} 
Table 5 shows the parameters used for the calculations and the elasticities of interest. For both states, we insert the elasticity of the LBT base of -0.45 estimated in the previous section. Thus, without fiscal equalization, the elasticity of LBT revenues would be 1-0.45 $=0.55$. However, the elasticity of LBT revenues after fiscal equalization (the term in square brackets) is 0.88 for the average municipality in Hesse and 0.98 in NRW. Hence, the decrease in the tax base resulting from an increase in the tax rate is compensated by fiscal equalization to a large extent in Hesse and almost completely in NRW. In NRW, a 1\% increase in the tax rate almost leads to a $1 \%$ increase in tax revenues after fiscal equalization, despite the sizable reduction of local business profits.

Table 5: Calculation of the elasticity of the total budget after fiscal equalization 2004

\begin{tabular}{lll}
\hline \hline & Hesse & North Rhine-Westphalia \\
\hline Marginal compensation rate $\alpha$ & 0.47 & 0.47 \\
Marginal compensation rate $\beta$ & 0.27 & 0.48 \\
Average effective tax rate $(t$ and $\bar{t}$ ) & 0.1667 & 0.1776 \\
Elasticity of the local business tax base (estimated) & -0.4456 & -0.4456 \\
Elasticity of local business tax revenues (calculated) & 0.8841 & 0.9777 \\
Share of business tax revenues in total budget, $t b / a$ & 0.2282 & 0.1691 \\
Elasticity of the municipality's total budget (calculated) & 0.2018 & 0.1654 \\
\hline The tax rate elasticity of the local business tax base is the econometrically estimated coefficient from Table 2, \\
first column. The elasticities of the local business tax revenues and of the municipality's total budget are \\
calculated using the term in square brackets of formula (3) and the complete formula, respectively. The other \\
parameters are extracted from Federal Statistical Office (2012).
\end{tabular}

The calculations demonstrate that tax competition for the LBT base is largely mitigated by fiscal equalization in Germany. This may partly internalize the horizontal externality. However, there is an inefficient vertical externality, because municipalities do not take into account that the national level also collects less revenues from the CIT if nation-wide taxable business profits shrink due to an increase in LBT rates (and are not only shifted from one municipality to the other within Germany).

Thus, the fiscal equalization scheme may help explain why the LBT rates have increased in Germany during the 1990s and 2000s against the trend of decreasing CIT rates in Germany and most other European and OECD countries, which have experienced increasing international tax competition for mobile capital due to accelerating globalization. Finally, 
taking into account the share of LBT revenues in the total budget of an average municipality, we obtain elasticities of a municipality's total budget with respect to the LBT rate of 0.20 in Hesse and 0.17 in NRW (Table 5).

\section{Conclusion}

We have estimated the elasticity of the local business tax (LBT) base with respect to the LBT rate in Germany, using the variation in tax rates over the more than 12,000 municipalities and over time for identification. The estimate for all firms is -0.45 , similar to the elasticity of the tax base with respect to the corporate income tax (CIT) base in Germany as estimated by Dwenger and Steiner (2012), and larger in absolute terms than the responsiveness of US corporations to the CIT rate as estimated by Gruber and Rauh (2007). Our analysis further shows that smaller firms that tend to be unincorporated and in the services sector are most responsive to the LBT rate. Corporations do not respond significantly to the LBT rate; they may primarily target the CIT for tax planning.

A methodological insight from our study is that calculating an approximate tax base from tax revenue data and estimating the elasticity using this approximation seems to result in a significant bias of the estimated elasticity away from zero. This must be considered when using country-level revenue data, for example the OECD tax revenue statistics, as is common in the empirical literature on the revenue effects of company taxation. To obtain unbiased estimates of the tax base elasticity, tax return data should be used.

Since we find a relatively strong decline of local taxable business profits in response to an increase in LBT rates, one might expect that tax competition among municipalities for the local tax base would lead to a race to the bottom of LBT rates. However, LBT rates have increased in the 1990s and 2000s, in contrast to CIT rates in Germany and most European and OECD countries, which have moved downward, presumably due to increasing international tax competition. We demonstrate that the different trend of the LBT rates may be explained 
by the German fiscal equalization scheme, which largely compensates municipalities for the loss in the local tax base when they increase LBT rates, and therefore mitigates local tax competition.

On the one hand, this way the fiscal equalization scheme may lead to a partial internalization of horizontal external effects between municipalities, which arise when a tax rate change in one municipality induces firms to move local taxable profits from one municipality to the other, and thus affects tax revenues of other municipalities as well. Our relatively large elasticity estimate suggests that such externalities would be sizable without a fiscal equalization scheme. On the other hand, the equalization scheme may intensify vertical externalities, because municipalities do not take into account that shrinking nation-wide taxable business profits as a result of higher LBT rates also lead to lower CIT revenues on the national level. More research is needed to assess the welfare effects. The significant elasticity of the LBT base we estimate strongly suggests that welfare effects of local business taxation are important and calls for further theoretical and empirical research in this area. 


\section{References}

Becker, Sascha O., Peter H. Egger, and Valeria Merlo, 2012. "How low business tax rates attract MNE activity: Municipality-level evidence from Germany.” Journal of Public Economics 96, 698-711.

Buettner, Thiess, 2005. "Zur Aufkommens- und Budgetwirkung der gemeindlichen Steuerpolitik: empirische Ergebnisse für Baden-Wuerttembergische Gemeinden.“ [About the revenue and budgetary effects of municipal tax policy: Empirical results for municipalities in Baden-Wuerttemberg.] Jahrbuch für Regionalwissenschaft-Review of Regional Research 25 (1), 27-43.

Buettner, Thiess, 2006. “The incentive effect of fiscal equalization transfers on tax policy.” Journal of Public Economics 90 (3), 477-497.

Buettner, Thiess, Fédéric Holm-Hadulla, Ruediger Parsche, and Christiane Starbatty, 2008. "Analyse und Weiterentwicklung des Kommunalen Finanzausgleichs in NordrheinWestfalen.” [Analysis and further development of the municipal fiscal equalization scheme in North Rhine-Westfalia.] Report for the Interior Ministry of North RhineWestfalia. ifo Economic Research Insitute, Munich, Germany. http://www.nrw.de/mediadatabase/Gutachten_des_ifo_Instituts.pdf.

Buettner, Thiess, Nadine Riedel, and Marco Runkel, 2011. "Strategic consolidation under formula apportionment.” National Tax Journal 64, 225-254.

Clausing, Kimberly A., 2007. “Corporate tax revenues in OECD countries.” International Tax and Public Finance 14, 115-133.

Devereux, Michael P., 2004. “Measuring taxes on income from capital.” In Soerensen, Peter B. (ed.), Measuring the tax burden on capital and labor, 35-72. MIT Press, Cambridge, MA.

Devereux, Michael P., 2007. "Developments in the taxation of corporate profit in the OECD since 1965: Rates, bases and revenues.” Working Paper No. 07/04. Oxford University Centre for Business Taxation, Oxford, UK.

Devereux, Michael P., Ben Lockwood, and Michela Redoano, 2008. “Do countries compete over corporate tax rates?” Journal of Public Economics 92 (5-6), 1210-1235.

Dwenger, Nadja, and Viktor Steiner, 2012. "Profit taxation and the elasticity of the corporate income tax base. Evidence from German corporate tax return data.” National Tax Journal, 117-150. 
Egger, Peter, Marko Koethenbuerger, and Michael Smart, 2010. "Do fiscal transfers alleviate business tax competition? Evidence from Germany.” Journal of Public Economics 94 (34), 235-246.

Federal Statistical Office, 2005. "Finanzen und Steuern. Realsteuervergleich, 2004.“ [Finances and Taxes. Comparison of impersonal taxes, 2004.] Fachserie 14 Reihe 10.1. Wiesbaden, Germany.

Federal Statistical Office, 2012. "Finanzen und Steuern. Realsteuervergleich, 2011.“ [Finances and Taxes. Comparison of impersonal taxes, 2011.] Fachserie 14 Reihe 10.1. Wiesbaden, Germany.

Feldstein, Martin, 1995. "The effect of marginal tax rates on taxable income: A panel study of the 1986 tax reform act.” Journal of Political Economy 103 (3), 551-572.

Fullerton, Don, 1984. “Which effective tax rate?” National Tax Journal 37 (1), 23-41.

Gordon, Roger H., Laura Kalambokidis, and Joel B. Slemrod, 2004. “A new summary measure of the effective tax rate on ílnvestment.” In Soerensen, Peter B. (ed.), Measuring the tax burden on capital and labor, 99-128. MIT Press, Cambridge, MA.

Gruber, Jonathan, and Joshua Rauh, 2007. “How elastic is the corporate income tax base?” In Auerbach, Alan J., James R. Hines Jr., and Joel B. Slemrod (eds.), Taxing corporate income in the 21st century, 140-163. Cambridge University Press, Cambridge, MA.

Gruber, Jonathan, and Emmanuel Saez, 2002. “The elasticity of taxable income: Evidence and implications.” Journal of Public Economics 84 (1), 1-32.

Katsimi, Margarita, and Vassilis Sarantides, 2012. "The impact of fiscal policy on profits.” Economic Inquiry 50(4), 1050-1068.

Onaran, Ozlem, Valerie Boesch, and Markus Leibrecht, 2012. "How does globalization affect the implicit tax rates on labor income, capital income, and consumption in the European Union?“ Economic Inquiry 50(4), 880-904. 


\section{Appendix}

Figure 1: Histogram of local business tax multipliers in Germany in 2004

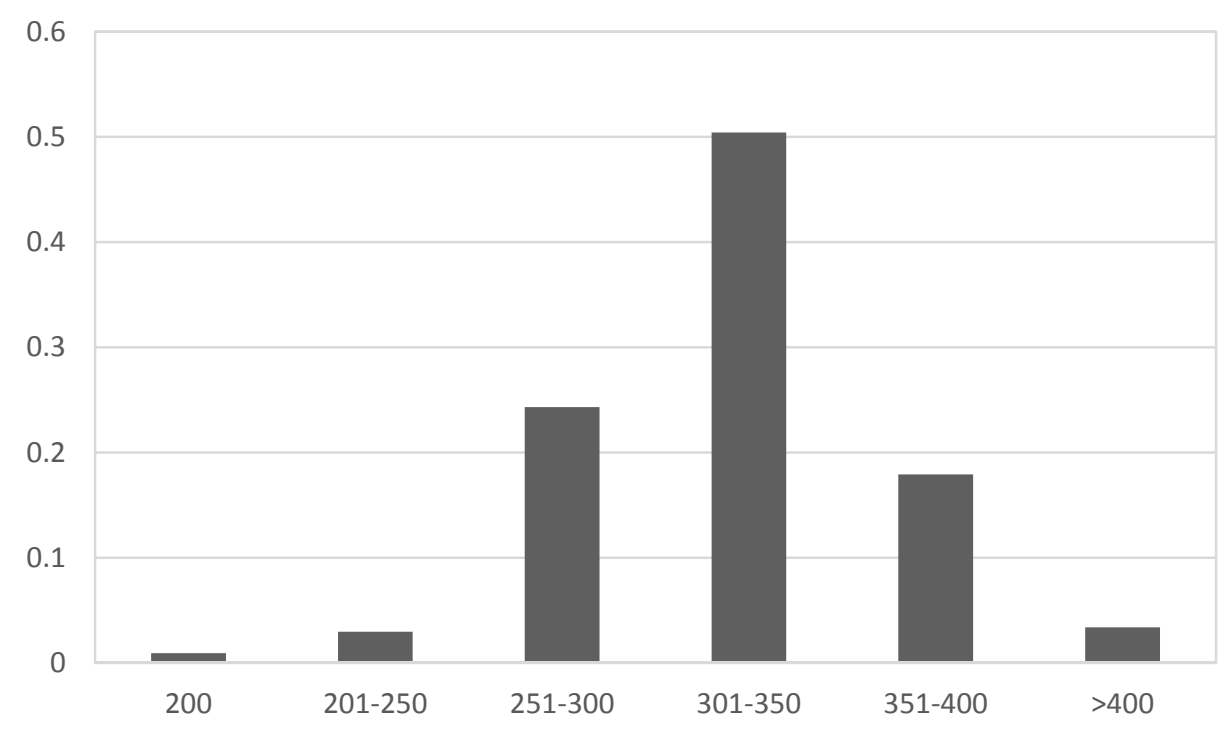

Source: Adapted from Federal Statistical Office (2005).

Figure 2: Average local business tax multipliers in Germany, 1992-2012

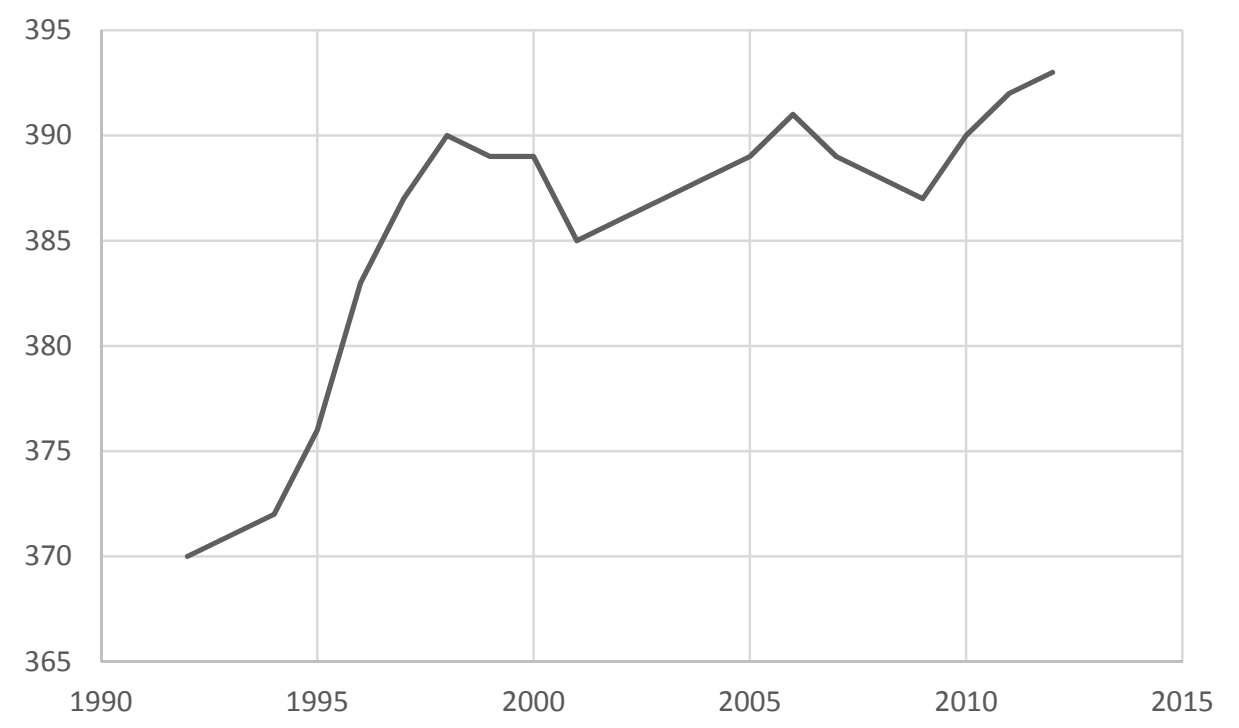

Source: Adapted from Federal Statistical Office (2005 and 2012). 